\title{
IMPLANTAÇÃO DE ACESSIBILIDADE EM AMBIENTE UNIVERSITÁRIO
}

\section{ARTIGO ORIGINAL}

SOUZA, Gabriel Costa Barreira de ${ }^{1}$, CAMELO, Paulo Damaglio², SOUZA, Rogério Carvalho $\mathrm{de}^{3}$

SOUZA, Gabriel Costa Barreira de. CAMELO, Paulo Damaglio. SOUZA, Rogério Carvalho de. Implantação de acessibilidade em ambiente universitário. Revista Científica Multidisciplinar Núcleo do Conhecimento. Ano. 07, Ed. 01, Vol. 01, pp. 104-129. Janeiro de 2022. ISSN: 2448-0959, Link de acesso: https://www.nucleodoconhecimento.com.br/engenharia-civil/implantacao-deacessibilidade, DOI: 10.32749/nucleodoconhecimento.com.br/engenhariacivil/implantacao-de-acessibilidade

\section{RESUMO}

Este artigo tem por finalidade executar um estudo sobre acessibilidade para 0 Centro das Universidades Associadas de Ensino - UNIFAE, localizado em São João da Boa Vista, estado de São Paulo. Tendo um enfoque nos principais tipos de deficiências (motora/sonora/visual), o estudo não apenas analisa o quadro de adequações atual, como também propõe melhorias para que haja uma maior inclusão de pessoas portadoras de necessidades especiais na universidade. $O$ estudo decorre através de análise teórica com base, principalmente, na Norma Regulamentadora 9050:2015, a qual define as condições construtivas necessárias para a inclusão de indivíduos portadores de necessidades especiais, assim como outras normas complementares. Para a análise é traçado um trajeto que passa pelos principais pontos de interesse da UNIFAE e, com base neste, realiza-se um estudo

\footnotetext{
${ }^{1}$ Graduação.

${ }^{2}$ Graduação.

${ }^{3}$ Orientador.
}

RC: 104683

Disponível em: https://www.nucleodoconhecimento.com.br/engenhariacivil/implantacao-de-acessibilidade 
com o auxílio de checklist, para constatar as necessidades de adaptações, medida que também ajuda na análise da sinalização a ser implementada.

Palavras-chave: Acessibilidade, deficiência, universidade, estudo de caso, civil.

\section{INTRODUÇÃO}

Este trabalho possui a finalidade de realizar uma investigação da acessibilidade nos prédios do Centro Universitário das Faculdades de Ensino - FAE (UNIFAE), São João da Boa Vista, SP, em relação aos alunos portadores de necessidades especiais, identificando as possíveis barreiras arquitetônicas, geradas devido a expansão do campus. Tendo enfoque em identificar a situação real dos locais que não estão de acordo com a NBR 9050:2015, foram levantadas possíveis soluções para a melhoria desse quadro, e sugestões para a implantação dessas adaptações atendendo a referida norma.

Segundo o IBGE (2010), o Brasil possuía cerca de $24 \%$ da sua população com pelo menos algum tipo de deficiência (motora, auditiva, visual, intelectual). Esse grupo por muitas vezes acaba por ser esquecido durante a elaboração de diversos projetos. Tendo isto em vista foi criado o Estatuto da Pessoa com Deficiência, que por sua vez se destina a inclusão de pessoas portadoras de deficiência na sociedade. Em seus artigos 57 e 58, de acordo com o Estatuto, se tem por obrigação consultar a norma NBR 9050:2015, durante a elaboração de projetos. Estes mesmos Artigos 57 e 58 do Estatuto da Pessoa com Deficiência, que amparados por uma medida provisória, se tornaram obrigatórios a partir de janeiro de 2020.

A Constituição Federal do Brasil possui dois artigos importantes para esse meio de estudo, que são por sua vez o Artigo 5 que garante o direito de ir e vir a todos os brasileiros em todo o território nacional. O Artigo 205 garante a todos o direito à educação, seja quem for. O que é algo extremamente relevante, pois é apenas através da formação que as pessoas adquirem um senso crítico, necessário para 
que a sociedade continue evoluindo, em todos os aspectos tanto sociais quanto científicos. (BRASIL, 1988)

Este projeto tem como objetivo executar um estudo da acessibilidade proporcionada pela UNIFAE, identificar barreiras arquitetônicas, e propor soluções com base nas normas regulamentadoras para adequar, melhorar e facilitar o acesso de pessoas com algum tipo de deficiência ou limitação à Instituição de Ensino Superior, Centro Universitário das Faculdades Associadas de Ensino - FAE (UNIFAE).

É de suma importância, a faculdade se adequar aos padrões das normas reguladoras e leis vigentes, permitindo, assim, que novos alunos com deficiência ou limitações espalhados pela região procurem a instituição, melhorando sua qualidade de vida, podendo exercer novas atividades e conseguir a conquista de um diploma de curso superior, que vem se tornando algo cada vez mais necessário.

\section{DESENVOLVIMENTO}

A Norma Regulamentadora 9050 da Academia Brasileira de Normas Técnicas (2015) estabelece critérios e parâmetros técnicos a serem observados quanto ao projeto, construção, instalação e adaptação do meio urbano e rural, e de edificações às condições de acessibilidade.

De acordo com a ABNT NBR 9050 (2015, p.2), acessibilidade é a

Possibilidade e condição de alcance, percepção e entendimento para a utilização, com segurança e autonomia, de espaços, mobiliário, equipamentos urbanos, edificações, transportes, informação e comunicação, inclusive seus sistemas e tecnologias, bem como outros serviços e instalações abertos ao público ou privado de uso coletivo, tanto na zona urbana como na rural, por pessoa com deficiência ou mobilidade reduzida.

A NBR 9050 (2015, p.1), também "Visa proporcionar a utilização de maneira autônoma, independente e segura do ambiente, edificações, mobiliário, equipamentos urbanos e elementos à maior quantidade possível de pessoas, independentemente de idade, estatura ou limitação de mobilidade ou percepção". 
Indicadores de um prédio adaptado, podem ser facilmente percebidos, em virtude que a grande maioria são itens visuais, em resumo acabam por ser, largura de portas e corredores, existência de banheiros adaptados com barras fixas, existência de sinalização tátil e sonora para locomoção de $\operatorname{PcD}$ (pessoas com deficiência), existência de elevadores adaptados, presença de vagas exclusivas, mobiliário adequado e calçadas uniformes e com fácil acesso. (NBR 9050, 2015)

Acessibilidade é um assunto que vem ganhando grande destaque nos últimos tempos, porém, é um problema que existe desde a pré-história. A humanidade sempre teve que lidar com anomalias desde sua origem como espécie, se torna até simples de se pensar, pois com o desconhecimento da medicina, nos primórdios uma ferida de caça poderia facilmente evoluir para um quadro mais sério, podendo causar uma possível dificuldade de movimento. Pode-se dizer que a principal mudança além da medicina, está na maneira como é observado este tipo de problema, a evolução no conceito de inclusão desta pessoa. (SILVA, 2009)

Com o avanço da medicina moderna, foi perdido o conceito de misticismo que envolviam certas deficiências, e foram sendo criadas iniciativas que de início não foram levadas muito a sério, mas com o passar do tempo tornaram-se leis como por exemplo:

Na Idade Média, mais atenção foi dada às pessoas pobres e com deficiência, principalmente devido à lei - "The Poor Law Act", lavrada em 1601, que mencionava, explicitamente, os pobres, os incapazes e os cegos, prevendo abrigo e suporte para estas pessoas. Desta data em diante e por mais duzentos anos, os cegos viviam em suas casas ou em instituições, os chamados "asylums", contando com algum suporte dos governantes. (MOTTA, 2004)

Atingindo todo o seu ápice global no ano de 1981, Ano Internacional das Pessoas com Deficiência que tinha por principal objetivo chamar a atenção, de todos os países e pessoas do mundo, para acelerar a criação de leis e iniciativas a âmbito global, cujo lema era "Participação plena e igualdade", onde foram publicados vários números a respeito da comunidade de deficiente, a fim de evidenciar o grande problema que este é, obtendo como maior resultado a formação do Programa 
Mundial de Ação para pessoas com deficientes, formulada pela Assembleia Geral das Nações Unidas em dezembro de 1982. (MINISTÉRIO DA EDUCAÇÃO, 1981)

A OMS (ORGANIZAÇÃO MUNDIAL DA SAÚDE, 2011), em 2011, elaborou uma pesquisa onde constatou que no mundo haviam por volta de 1 bilhão de pessoas que portavam algum tipo de deficiência, e essa massa da população por mais que existam iniciativas, ongs que cuidam desta classe, ainda se trata de um ramo da população que acaba sendo extremamente esquecido uma vez constatado a grande falta de dados, e pesquisas a respeito dessa comunidade, ainda se constatou que 80\% dessas pessoas se localizam em países emergentes. (WORLD REPORTON DISABILITY, 2011)

Segundo (IBGE, 2010) o Brasil possui cerca de 190.755.799 milhões de habitantes dos quais cerca de 45.606.048 milhões possuem pelo menos um tipo de deficiência (visual, motora, auditiva, mental/intelectual) o que vem a representar cerca de aproximadamente $23.92 \%$ da população total do país. Baseados nesses dados identifica-se um grande volume de pessoas deficientes, que também têm direito de ir a qualquer lugar como todas as pessoas não portadoras de necessidades especiais.

Atualmente o Brasil encontra-se em constante evolução, com isso o estudo se torna cada vez mais necessário para todas as pessoas. O ambiente universitário, onde se encontra a maior pluralidade de ideias, acaba por ajudar não só na formação de novos profissionais, mas também no desenvolvimento de seu senso crítico, assim não só melhorando a vida das pessoas, mas também mantendo o pensamento das pessoas em constante evolução.

Conforme os dados do INEP (2018) apontam que o número de universitários chega a 8.45 milhões, enquanto deste número pouco mais de 43.500 portam necessidades especiais, ou seja, apenas $0.5 \%$ do total, sendo assim se tem uma boa ideia de quão esquecida essa classe de pessoas acaba por ser.

Pela Medida Provisória № 917, de 31 de dezembro de 2019, os artigos 57 e 58, da lei 13.146 passam a exercer papel de lei, assim garantindo que todas as edificações

RC: 104683

Disponível em: https://www.nucleodoconhecimento.com.br/engenhariacivil/implantacao-de-acessibilidade 
independente de públicas ou privadas devem apresentar projetos os quais devem ser pensados para a inclusão das pessoas portadoras de deficiência no seu nicho de interessados, e permitir que esses usufruam dos serviços/espaço desses edifícios de forma "independente" sem necessariamente a presença de alguém para ajudá-lo a se locomover nas áreas em que Ihe é permitida, uma ideia bem similar ao conceito de "mobilidade urbana". (BRASIL, 2019)

Conforme Antunes e Simões (2013), a questão da mobilidade é de suma importância visto que ela eleva a qualidade de vida da população, dado que os deslocamentos são diários e frequentes, comumente o usuário escolhe o transporte pelo qual ele se desloca com qualidade, segurança e de forma eficiente.

O maior avanço nesta área no país, foi a criação das Normas Regulamentadoras, sendo a maior referência no assunto a NBR 9050, criada em 1985 pela Associação Brasileira de Normas Técnicas, que hoje se encontra em sua terceira edição, onde tem por objetivo "Estabelecer critérios e parâmetros técnicos a serem observados quanto ao projeto, construção, instalação e adaptação do meio urbano e rural, e de edificações às condições de acessibilidade". ABNT NBR 9050 (2015, p.1).

\section{UNIVERSIDADE}

O local de estudo é o Centro Universitário das Faculdades de Ensino - FAE (UNIFAE), situada no Largo Engenheiro Paulo de Almeida Sandeville 15 - Jardim Santo André, São João da Boa Vista - SP, 13870-377, que vem em constante expansão, possui hoje por volta de $20.010,00 \mathrm{~m}^{2}$, sendo sua área construída cerca de 15.065,00 m², distribuída em 13 prédios, sendo salas de aula, laboratórios e prédios administrativos. 
Figura 1 - Campus UNIFAE

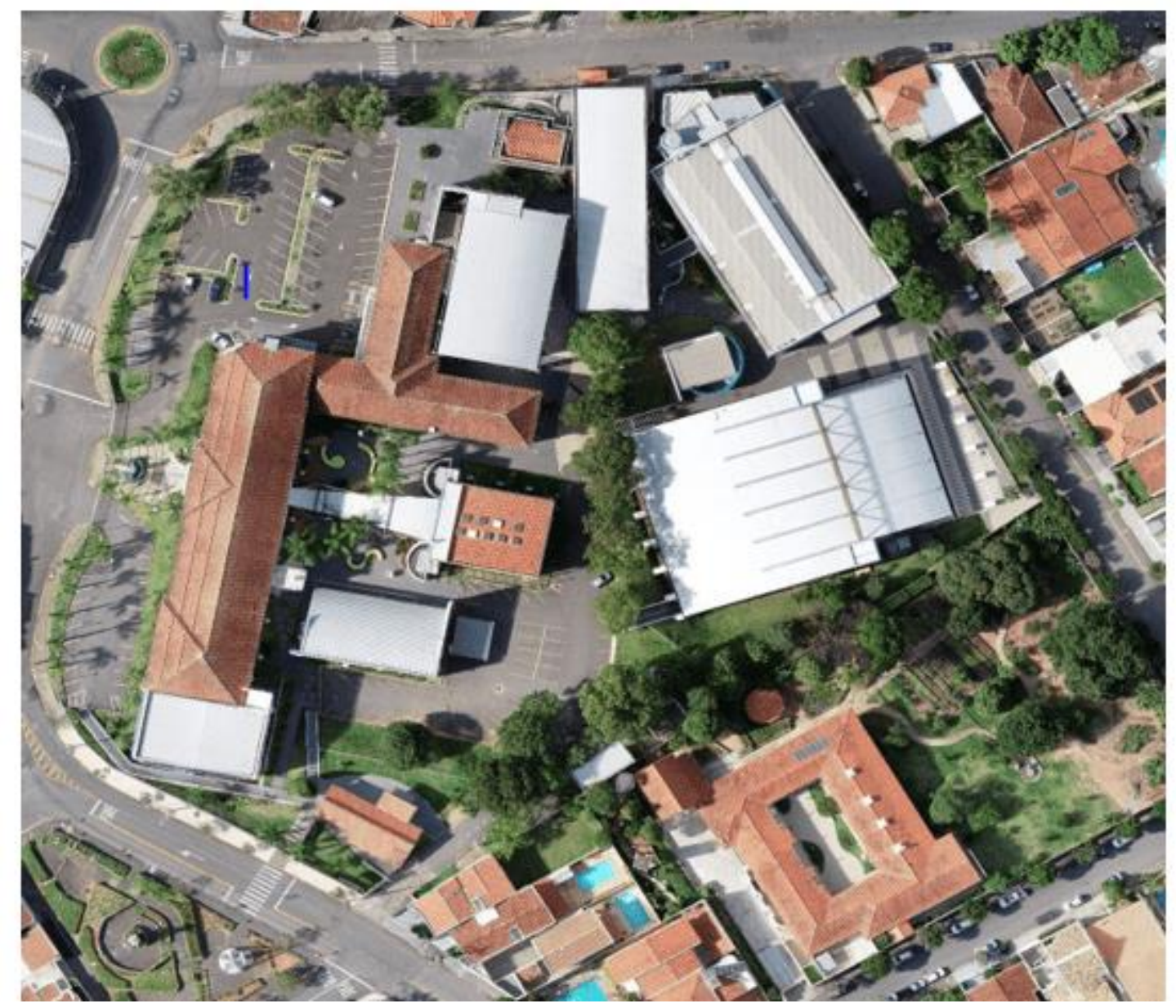

fonte: autor

\section{REFERENCIAL TEÓRICO}

Os indicadores a seguir têm como base os parâmetros normatizados pela ABNT NBR 9050:2015

\section{- Vagas Estacionamento}

O item 6.14 da norma define a existência de dois tipos de vagas reservadas, sendo a destinada a veículos que conduzem idosos ou sejam conduzidos por eles, e aquelas destinadas a veículos que conduzem ou são conduzidos por pessoas com deficiência. Ambas devem conter sinalização vertical que não afetem a área dos 
veículos, devem estar preferencialmente próximas às entradas do ambiente, para evitar deslocamentos desnecessários, às destinadas a $\mathrm{PcD}$ devem conter ademais espaço adicional de no mínimo 1,20m de largura, podendo ser compartilhado por mais de uma vaga caso o local permita, estarem vinculadas as rotas que levem a pólos de atração preferencialmente evitando deslocamentos entre veículos, conter piso estável e regular, com distância de percurso máximo entre vaga e acesso a edificação ou elevadores de no máximo $50 \mathrm{~m}$. O estacionamento deve dispor de uma rota de circulação segura com largura mínima de $1,20 \mathrm{~m}$ que leve ao local de interesse, sendo essa componente da rota acessível, os percentuais de vagas são definidos por legislação específica. (NBR 9050, 2015)

\section{- Símbolos Visuais}

A norma também preceitua o conceito relacionado a linguagem, que se define por um conjunto de símbolos e regras de aplicação, as quais constituem um sistema de comunicação podendo ser visual/tátil/sonoro. A linguagem visual deve seguir: premissas de texto, dimensionamento, contraste de texto e símbolos, garantindo que pessoas com baixa visão possam constatar, o contraste se dá em especial por utilização de claro-escuro, que chame a atenção do observador, deve ser usado tanto na linguagem visual, para informar os caminhos e os perigos no percurso a fim de garantir plena compreensão dos usuários. (NBR 9050, 2015)

Símbolos visuais devem seguir a proporção de altura de 1/200 da distância visada, com mínimo de $8 \mathrm{~cm}$, com fontes tipográficas já definidas, o desenho deve conter contornos fortes e bem definidos, formas simples com poucos detalhes, estabilidade da forma, e uso dos símbolos de padrão internacional. A utilização de cores nos sinais deve seguir a norma própria NR 26 - MT a qual designa as cores e locais de utilização. (NBR 9050, 2015)

- Linguagem tátil

Quanto a letras e números táteis, seu contraste é dado pelo relevo, são recomendadas escritas em caixa alta e baixa para as sentenças, uso de frases

RC: 104683

Disponível em: https://www.nucleodoconhecimento.com.br/engenhariacivil/implantacao-de-acessibilidade 
curtas escritos de preferência na horizontal, relevos de pisos táteis e escrita em braile requerem um bom controle dimensional. $\mathrm{Na}$ escrita os caracteres seguem as seguintes condições, fonte conforme predefinida, relevo entre $0.8 \mathrm{~mm}$ a $1.2 \mathrm{~mm}$, altura dos caracteres de $15 \mathrm{~mm}$ a $50 \mathrm{~mm}$, distância mínima entre caracteres $1 / 5 \mathrm{da}$ altura da letra (H), distância entre linha 8 mm. (NBR 9050, 2015)

Já os símbolos táteis devem seguir: altura do símbolo com proporção de 1/200 em relação a visada não podendo ser menor que $80 \mathrm{~mm}$, e o desenho obrigatoriamente seguir as condições, formas simples com poucos detalhes e constante, contornos fortes e bem definidos, altura mínima dos símbolos de $80 \mathrm{~mm}$, relevo entre $0.6 \mathrm{~mm}$ a $1.2 \mathrm{~mm}$, distância entre símbolos e texto de $8 \mathrm{~mm}$, símbolos em padrão internacional. (NBR9050, 2015)

- Braille

Braille deve estar posicionado abaixo dos símbolos e textos táteis, quando for feita em impressos perde-se esta necessidade, para sentenças longas a utilização de Braille deve estar alinhada à esquerda junto ao texto em relevo, em relação aos pontos da escrita estes devem ser arredondados em forma esférica conforme figura abaixo.

Figura 2 - Arranjo geométrico dos pontos em Braille e formato do relevo
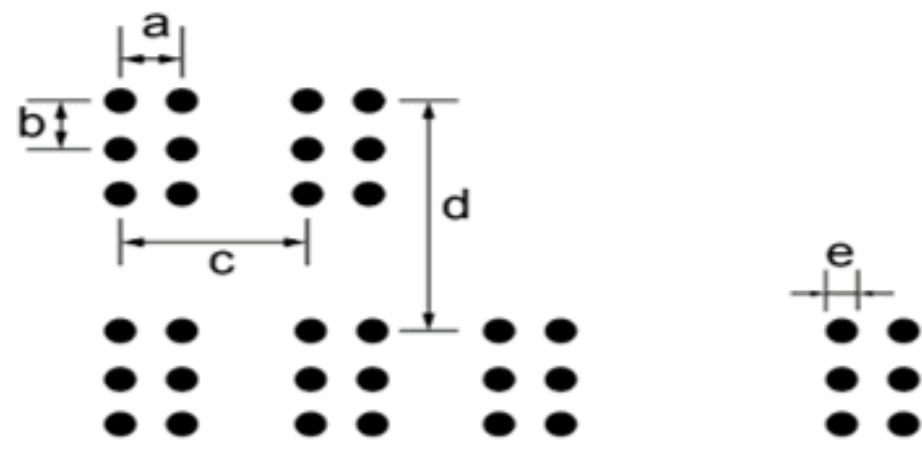

Fonte: ABNT NBR 9050 (p. 37)

RC: 104683

Disponível em: https://www.nucleodoconhecimento.com.br/engenhariacivil/implantacao-de-acessibilidade 
Tabela 1 - Distanciamento dos pontos em Braille

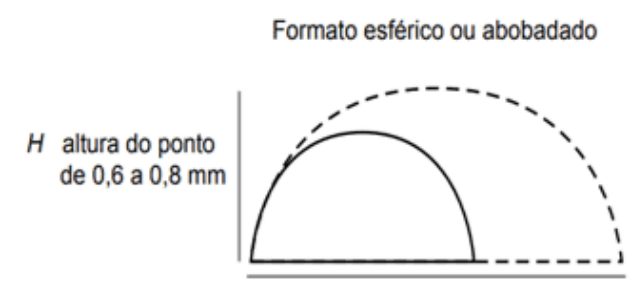

D diâmetro da base $1,2 \mathrm{~mm}$ a $2 \mathrm{~mm}$

\begin{tabular}{|c|c|c|c|c|c|}
\hline a & b & c & d & $\begin{array}{c}\text { Diâmetro do } \\
\text { ponto } \mathbf{e}=\mathbf{D}\end{array}$ & $\begin{array}{c}\text { Altura do } \\
\text { ponto } \mathbf{H}\end{array}$ \\
\hline 2,7 & 2,7 & 6,6 & 10,8 & De 1,2 a 2,0 & De 0,6 a 0,8 \\
\hline *D - diâmetro
\end{tabular}

fonte: ABNT NBR 9050 (p. 37)

\section{- Sinalização Sonora}

Em relação à linguagem e sonora, esta permite que pessoas com deficiência visual identifiquem os ambientes com facilidade, por cada ambiente conter um som distinto com relação ao som que é emitido por ambiente, sons compostos na forma de informações verbais ou não, definindo-se geralmente em 3 tipos, localização tem por finalidade orientar sobre a localização de um elemento em determinado espaço, os sinais devem ser intermitentes com período de 1 ciclo por segundo $\pm 10 \%$, advertência tem a propriedade de alerta prévio a instrução são também intermitentes com período de 5 ciclos por segundo $\pm 10 \%$, pôr fim a sinalização de instrução deve instruir uma ação de maneira positiva e afirmativa, quando usados em rotas de fuga essa sinalização deve ser contínua. (NBR 9050, 2015)

Sinais sonoros verbais, podem ser digitalizados ou sintetizados, conter apenas uma sentença integra e estar na forma ativa e imperativa. Já sinais sonoros de localização e advertência não verbais codificados devem ser emitidos nas frequências $100 \mathrm{~Hz}, 1000 \mathrm{~Hz}$ e $3000 \mathrm{~Hz}$, para sinais de instrução há possibilidades de outras frequências entre $100 \mathrm{~Hz}$ e $3000 \mathrm{~Hz}$, em nenhum caso transcender 3000 $\mathrm{Hz}$.

RC: 104683

Disponível em: https://www.nucleodoconhecimento.com.br/engenhariacivil/implantacao-de-acessibilidade 


\section{- Elevadores}

Se tratando de acessibilidade a 9050:2015 define que elevadores e plataformas elevatórias tanto verticais ou horizontais, ao lado da porta devem conter número do pavimento, os painéis de chamada devem conter informações de sua operação ambas em relevo e em Braille e estar compatíveis tanto com NBR NM 313 e ABNT NBR ISO 9386-1.

\section{- Sinalização Tátil}

A sinalização tátil e visual no piso, tem por intento, indicar direção de caminhos ou alerta nos mesmos, conforme normas específicas, o contraste com os demais pisos é dado pelo contraste visual e relevo. Todos os pisos táteis têm por finalidade 4 funções principais: identificação de perigos como desníveis e rampas (sinalização tátil de alerta), fazer a condução orientando um deslocamento seguro e direto (sinalização tátil direcional), mudança de direção expondo pontos onde há outros percursos (sinalização tátil de alerta), função de marcação de atividade a qual orienta sobre posicionamento adequado para uso de serviços ou equipamentos (ambas das sinalizações). (ABNT NBR 16537, 2016)

Devido a grande maioria de utilizadores serem pessoas portadoras de grande dificuldade visual, com o auxílio da bengala tátil, o percurso deve ser o mais direto possível, para não confundir o utilizador com poucas informações ou com o excesso das mesmas. A sinalização tátil deve ser antiderrapante durante todo o ciclo de vida útil do ambiente interno/externo sob qualquer condição, ter relevo contrastante conforme tipo de sinalização (alerta/direcional) em relação ao piso adjacente, para ser percebida claramente com o auxílio da bengala longa e ter contraste de luminância em relação ao piso adjacente na condição seca ou molhada sendo o valor mínimo desse contraste 30 pontos da escala relativa, devendo ser garantido esse contraste durante toda a vida da edificação, evitando-se o uso simultâneo das cores verde e vermelha. (ABNT NBR 16537, 2016) 
A sinalização tátil e visual de alerta, tem por finalidade, informar a respeito de desníveis, situações de risco permanentes a qual a bengala tátil não consegue detectar, orientar sobre posicionamento correto para a utilização de mobiliários, informar mudanças nos percursos, presença de escadas, patamares, rampas, travessias de pedestres o piso por sua vez é composto de um conjunto de relevos troncocônicos. (ABNT NBR 9050, 2015)

Sinalização tátil e visual direcional deve ser instalada no sentido preferencial do deslocamento das pessoas, quando há falta de uma linha-guia identificável, em lugares tanto externos quanto internos, os relevos da sinalização são lineares e ficam regularmente dispostos. (fotos pág. 50) (ABNT NBR 9050, 2015)

\section{- Rampas}

Conforme a ABNT NBR 9050 (2015, p. 59), as rampas devem ter inclinação de acordo com os limites estabelecidos na Tabela 1.

Para inclinação entre 6,25 \% e 8,33 \%, é recomendado criar áreas de descanso (6.5.) nos patamares, a cada $50 \mathrm{~m}$ de percurso. Excetuam-se deste requisito as rampas citadas em 10.4 (plateia e palcos), 10.12 (piscinas) e 10.14 (praias).

Tabela 1 - Inclinação máxima de rampas de acesso

\begin{tabular}{|l|l|l|}
\hline $\begin{array}{l}\text { Desníveis máximos de } \\
\text { cada segmento de rampa } \\
\text { h }\end{array}$ & $\begin{array}{l}\text { Inclinação admissível em } \\
\text { cada segmento de rampa i \% }\end{array}$ & $\begin{array}{l}\text { Número máximo de } \\
\text { segmentos de rampa }\end{array}$ \\
\hline $\mathrm{m}$ & & \\
\hline $\mathbf{1 , 5 0}$ & $5,00(1: 20)$ & Sem limite \\
\hline $\mathbf{1 , 0 0}$ & $5,00(1: 20)<\mathrm{i} \leq 6,25(1: 16)$ & Sem limite \\
\hline $\mathbf{0 , 8 0}$ & $6,25(1: 16)<\mathrm{i} \leq 8,33(1: 12)$ & 15 \\
\hline
\end{tabular}

Fonte: ABNT NBR 9050 (p. 59) 


\section{MÉTODOS}

Foram realizadas pesquisas e visitas prévias ao campus, entrevistas com alunos, docentes, funcionários com o intuito de mapear as principais rotas que os alunos veem em a adotar durante os deslocamentos no centro universitário, assim possibilitando mapear os caminhos mais críticos para a verificação, tomado como base o trajeto feito por Schmitz e Silveira (2019) na universidade de Santa Cruz do Sul.

O trajeto, tema deste artigo, foi escolhido por ser uma das principais entradas do campus, e o mesmo passa pelos principais pontos de interesse presentes na faculdade.

Decorreram pesquisas e conversas com profissionais, para a obtenção de uma maior gama de possíveis soluções, assim podendo chegar a que mais se adequa ao desafio proposto.

Para uma fácil constatação dessas barreiras, fora usado um checklist com base nos parâmetros da NBR 9050/2015, o qual permite averiguação rápida de forma metódica e coerente destes obstáculos.

Foi criado um trajeto pelo campus da universidade ligando o local de embarque e desembarque de estudantes a todos os pontos de interesse principais da UNIFAE, sendo estes: Salas de aula, sanitários, auditório, área social, secretaria, biblioteca, laboratório e cantina. 
Figura 4 - Trajeto principal e trechos

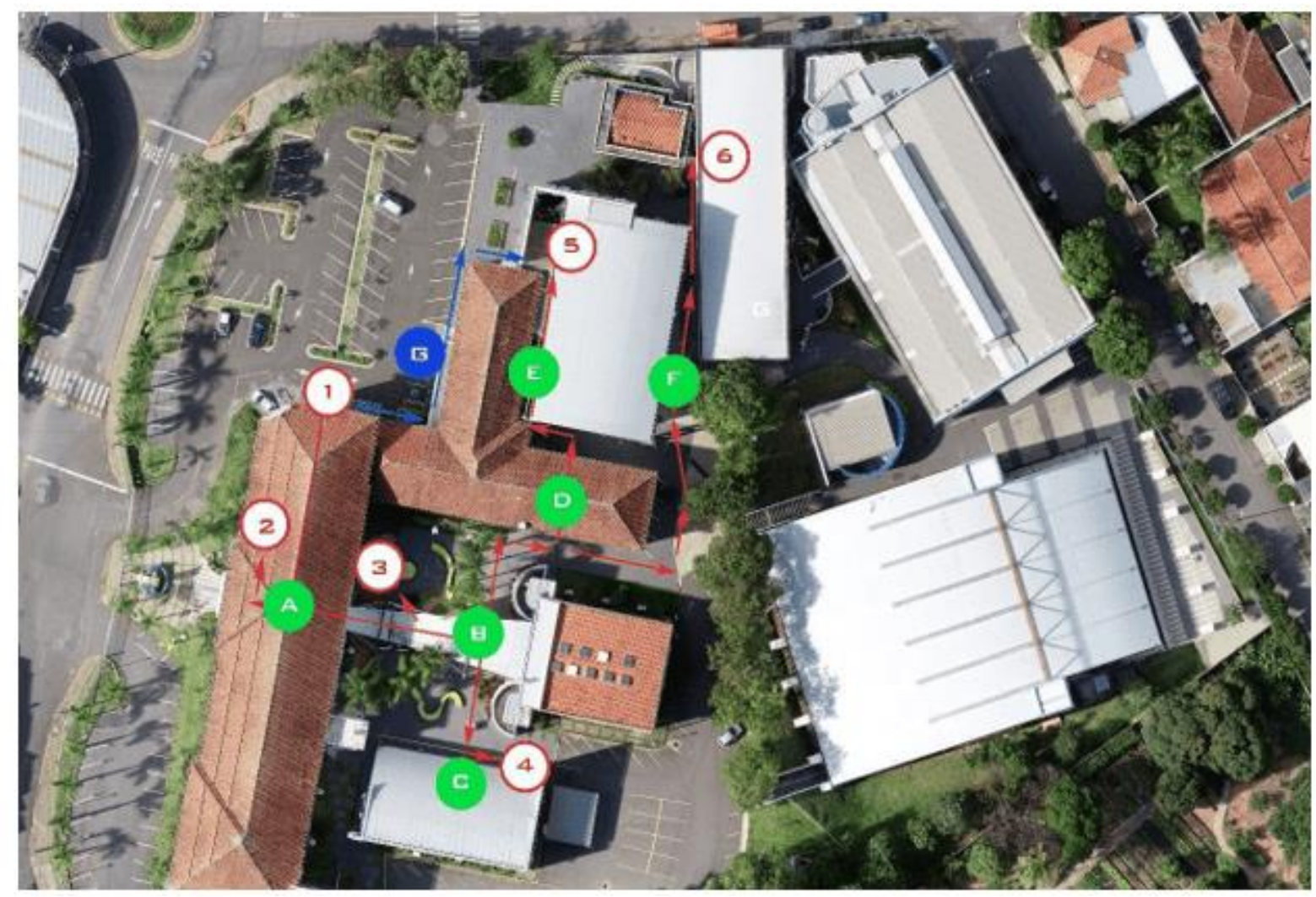

fonte: autor

Legenda:

- Estacionamento embarque/ desembarque

- Auditório

- Cantina

- Biblioteca

- Secretaria/ Bloco B

- Laboratório

\section{RESULTADOS E DISCUSSÕES}

A inexistência de sinalização tátil (caracteres em relevo e em Braille) em determinados pontos do campus, sinalizações sonoras, passeio acidentado e a falta

RC: 104683

Disponível em: https://www.nucleodoconhecimento.com.br/engenhariacivil/implantacao-de-acessibilidade 
de elevadores são os principais agravantes na questão da mobilidade e acessibilidade no campus da UNIFAE.

$\mathrm{Na}$ figura 4, além dos pontos de interesse abordados, foram adicionadas demarcações de trechos representados pelos círculos verdes e azuis, para que o leitor observe da maneira mais simples e didática possível os resultados obtidos nesta pesquisa.

Foi utilizada como base a tabela de Schmitz e Silveira (2019) que foi aprimorada para ser mais atrativa e interativa ao leitor.

Neste projeto foram adotadas três categorias de classificação de acessibilidade, sendo estas indicadas no canto superior esquerdo de cada tabela a seguir. Classificadas como acessíveis são os locais onde qualquer pessoa P.N.E (portadores de necessidades especiais) ou P.M.R (portadores de mobilidade reduzida) pode ter acesso de modo seguro.

Parcialmente acessíveis são pontos onde apenas alguns indivíduos podem ter acesso seguro, porém, o local não se encontra devidamente adaptado a todos que o acessam. Como por exemplo, o elevador vertical: Este é acessível a cadeirantes, porém, não é seguramente acessível a deficientes visuais, pela ausência de sinalização sonora.

Classificadas como não acessíveis, são trechos onde oferecem riscos de acidente ou dificuldade de transposição a qualquer pessoa P.N.E ou P.M.R.

Para este estudo, tem-se como início o estacionamento, representado pelo ponto 1 na figura 5 , serão seguidos os trajetos em ordem alfabética ( $A, B, C, D, E, F$ e G). 
Tabela 2 - Síntese dos resultados obtidos com o trecho A

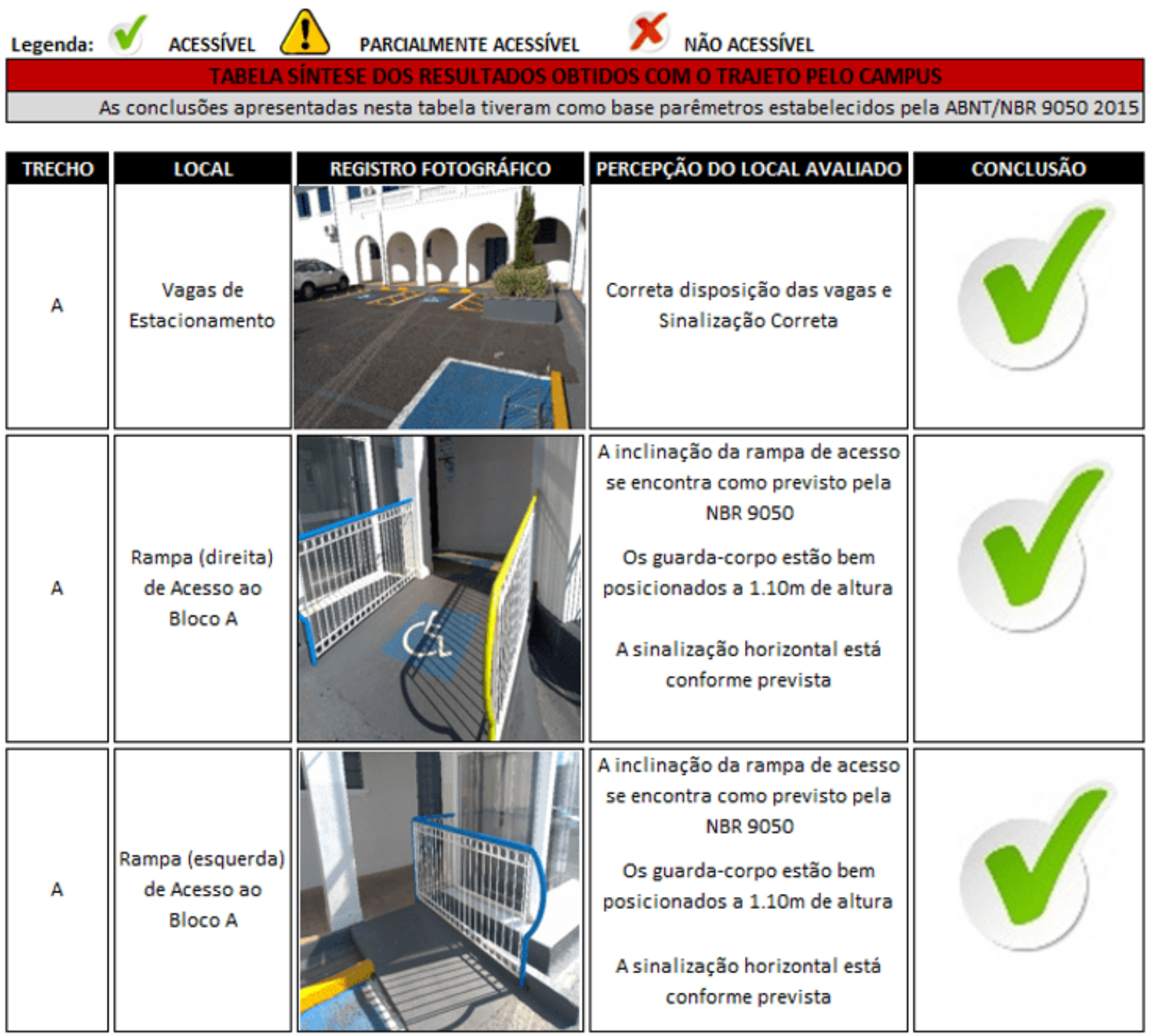

fonte: autor

O ponto 1, caracteriza-se pelo estacionamento e as vagas exclusivas para P.N.E. e P.M.R. Este se encontra conforme o previsto pela ABNT NBR 9050, que visa a presença de sinalizações verticais, horizontais e rampas conforme abordado no referencial teórico na tabela 1.

Disponível em: https://www.nucleodoconhecimento.com.br/engenhariacivil/implantacao-de-acessibilidade 
Tabela 3 - Síntese dos resultados obtidos com o trecho A
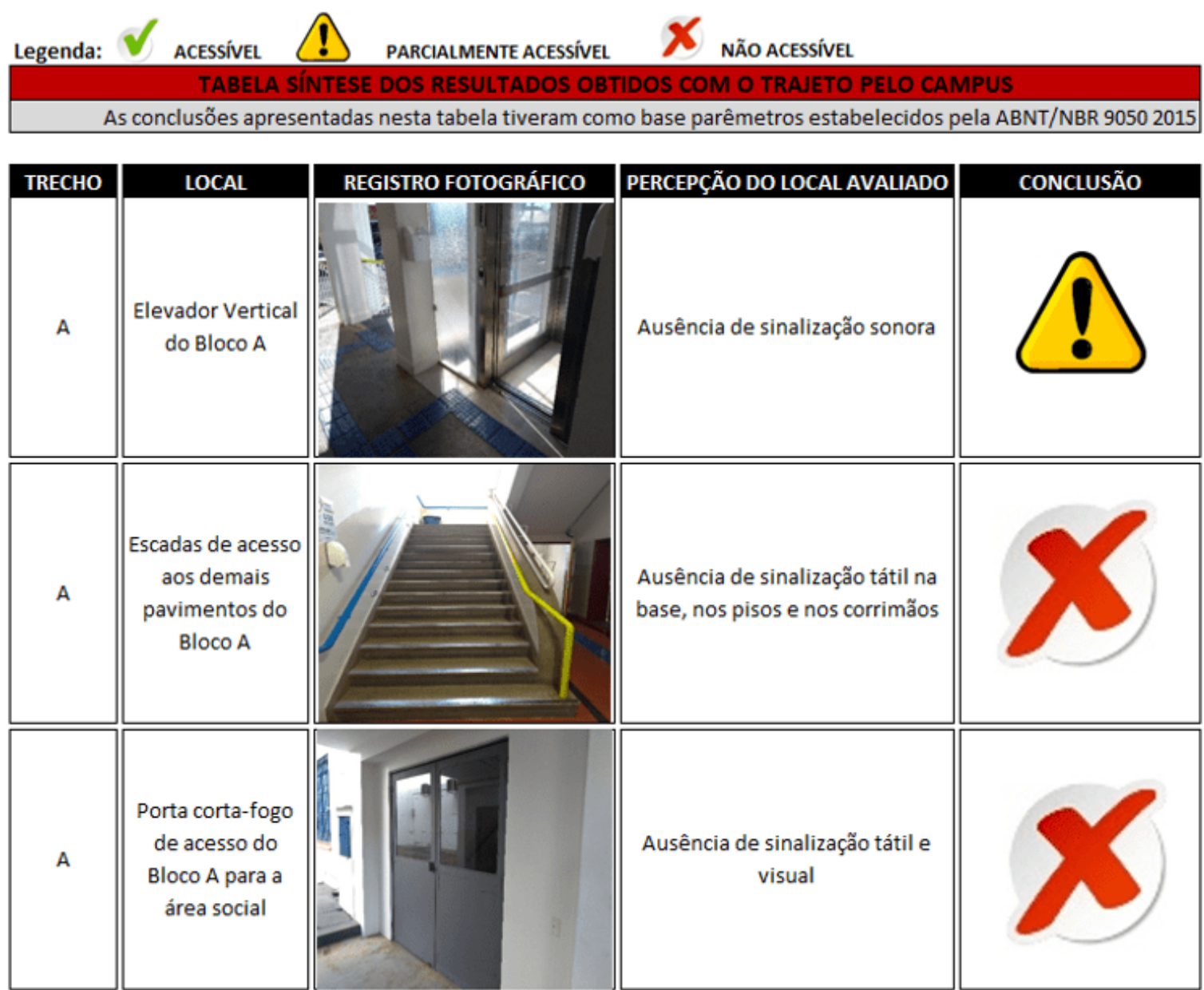

fonte: autor

Seguindo o trecho A, demonstrado na figura 4, este é onde encontram-se as primeiras barreiras para acessibilidade.

O único elevador vertical presente no Campus, se localiza no Bloco A. Ele se encontra acessível a P.M.R, porém, apresenta limitações para que portadores de deficiência visual embarquem, fazendo com que estes indivíduos busquem por ajuda para se localizarem pelos pavimentos em que o elevador se encontra, logo não possuindo autonomia própria. 
Sobre a sinalização tátil e sonora para deficientes visuais, no elevador a NBR 9050:2015 diz:

"Externa e internamente nos elevadores verticais ou inclinados, deve haver sinalização tátil e visual estabelecida na Seção 5, informando:

1. a) instrução de uso, fixada próximo à botoeira;

2. b) indicação da posição para embarque e desembarque;

3. c) indicação dos pavimentos atendidos nas botoeiras e batentes;

4. d) dispositivo de chamada dentro do alcance manual." ABNT NBR 9050 (2015, p.67).

Outro ponto, este que é completamente inacessível a P.N.E e P.M.R. são as escadas. Há ausência de sinalizações táteis em todas as escadas fixas do campus da universidade. Conforme mencionado na NBR 9050: "Os corrimãos de escadas fixas e rampas devem conter sinalização tátil (caracteres em relevo e em Braille), identificando o pavimento. "Essa sinalização deve ser instalada na geratriz superior do prolongamento horizontal do corrimão” ABNT NBR 9050 (2015, p. 45)

A Norma Técnica também cita que: "A sinalização visual dos degraus de escada deve ser:

a) aplicada aos pisos e espelhos em suas bordas laterais e/ou nas projeções dos corrimãos, contrastante com o piso adjacente, preferencialmente fotoluminescente ou retroiluminado;

b) igual ou maior que a projeção dos corrimãos laterais, e com no mínimo $7 \mathrm{~cm}$ de comprimento e $3 \mathrm{~cm}$ de largura;

c) fotoluminescente ou retro iluminada, quando se tratar de saídas de emergência e/ou rota de fuga." ABNT NBR 9050 (2015, p. 46)

Sobre corrimãos, a norma diz: 
Os corrimãos devem ser instalados em rampas e escadas, em ambos os lados, a $0,92 \mathrm{~m}$ e a $0,70 \mathrm{~m}$ do piso, medidos da face superior até o ponto central do piso do degrau (no caso de escadas) ou do patamar (no caso de rampas) [...] Os corrimãos laterais devem ser contínuos, sem interrupção nos patamares das escadas e rampas, e devem prolongar-se paralelamente ao patamar, pelo menos por $0,30 \mathrm{~m}$ nas extremidades, sem interferir com áreas de circulação ou prejudicar a vazão [...] As extremidades dos corrimãos devem ter acabamento recurvado, ser fixadas ou justapostas à parede ou piso, ou ainda ter desenho contínuo, sem protuberâncias. (ABNT NBR 9050, 2015, p. 63)

Por fim, a sinalização tátil em relevo deve encontrar-se na base e no final da extensão da escada, na situação avaliada pelo grupo a sinalização encontra-se ausente em todas as escadas do Bloco A.

Existem também em cada pavimento do bloco $A$, rotas de saída de emergência, portas corta-fogo, que se encontram no momento do estudo sem sinalização adequada. Conforme a NBR 9050:2015 diz: "Nas escadas que interligam os diversos pavimentos, inclusive nas de emergência, junto às portas corta-fogo, deve haver sinalização tátil, visual e/ou sonora, informando o número do pavimento. A mesma informação deve ser sinalizada nos corrimãos” ABNT NBR 9050 (2015, p. 50).

Tabela 4 - Síntese dos resultados obtidos com o trecho A

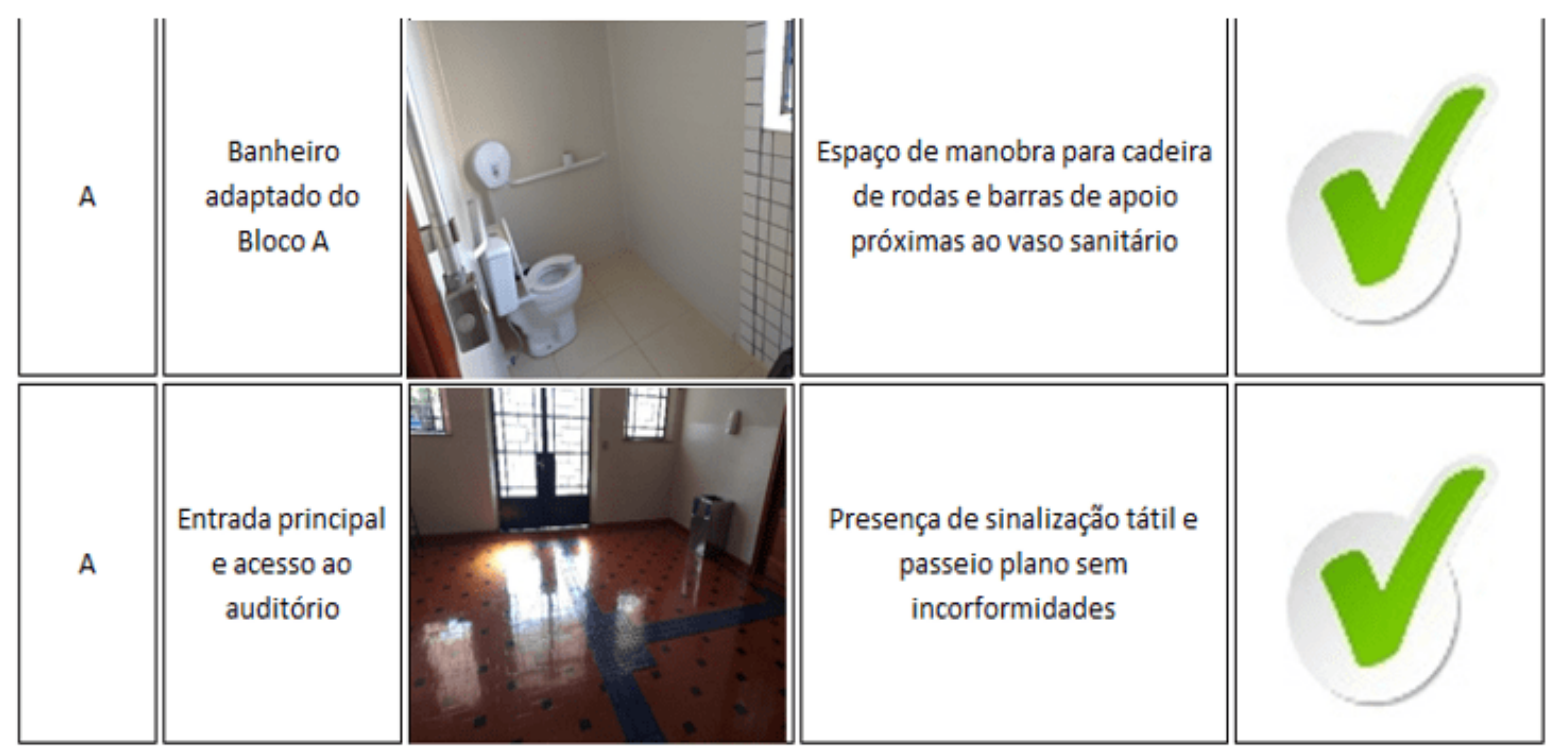

fonte: autor

RC: 104683

Disponível em: https://www.nucleodoconhecimento.com.br/engenhariacivil/implantacao-de-acessibilidade 
O Bloco A possui sanitários exclusivamente adaptados em todos os pavimentos. Estes se encontram próximos a rotas acessíveis e estão corretamente adaptados.

Tabela 5 - Síntese dos resultados obtidos com o trecho B

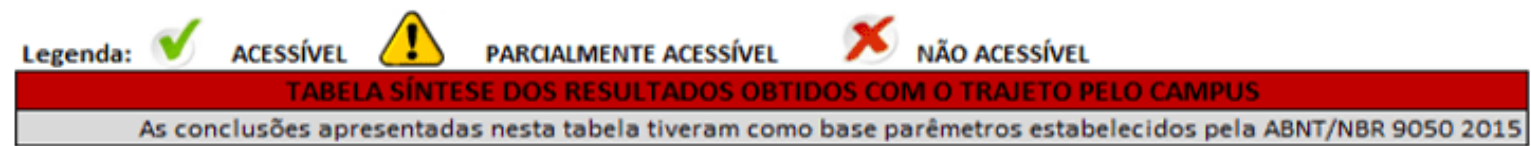

\begin{tabular}{|c|c|c|c|c|}
\hline TRECHO & LOCAL & REGISTRO FOTOGRÁFICO & PERCEPÇÃO DO LOCAL AVALIADO & CONCLUSÃO \\
\hline B & $\begin{array}{c}\text { Entrada para área } \\
\text { social }\end{array}$ & & $\begin{array}{c}\text { Presença de sinalização tátil e } \\
\text { passeio plano sem } \\
\text { incorformidades }\end{array}$ & \\
\hline B & Cantina & & $\begin{array}{c}\text { Presença de sinalização tátil e } \\
\text { passeio plano sem } \\
\text { incorformidades } \\
\text { Piso escorregadio quando } \\
\text { molhado, podendo causar } \\
\text { acidentes }\end{array}$ & \\
\hline B & $\begin{array}{c}\text { Passeio de acesso } \\
\text { à biblioteca }\end{array}$ & & $\begin{array}{c}\text { Presença de sinalização tátil e } \\
\text { passeio plano sem } \\
\text { incorformidades }\end{array}$ & \\
\hline B & $\begin{array}{c}\text { Passeio de acesso } \\
\text { aos Blocos B e C }\end{array}$ & & Ausência de sinalização tátil & \\
\hline
\end{tabular}

fonte: autor

A entrada para a área social encontra-se dentro dos parâmetros previstos pela ABNT NBR 9050, conta com sinalização tátil no passeio e piso de concreto antiderrapante. 
O trecho em frente à cantina, conta com um deck de madeira, que se torna escorregadio quando molhado, aumentando o risco de acidentes. De acordo com a NBR 9050 "Os materiais de revestimento e acabamento devem ter superfície regular, firme, estável, não trepidante para dispositivos com rodas e antiderrapante, sob qualquer condição (seco ou molhado)". ABNT NBR 9050 (2015, p. 55).

O passeio de acesso ao Bloco B e C também se encontra parcialmente adaptado, pois não conta com a instalação de sinalização tátil sobre o passeio.

Tabela 6 - Síntese dos resultados obtidos com o trecho C

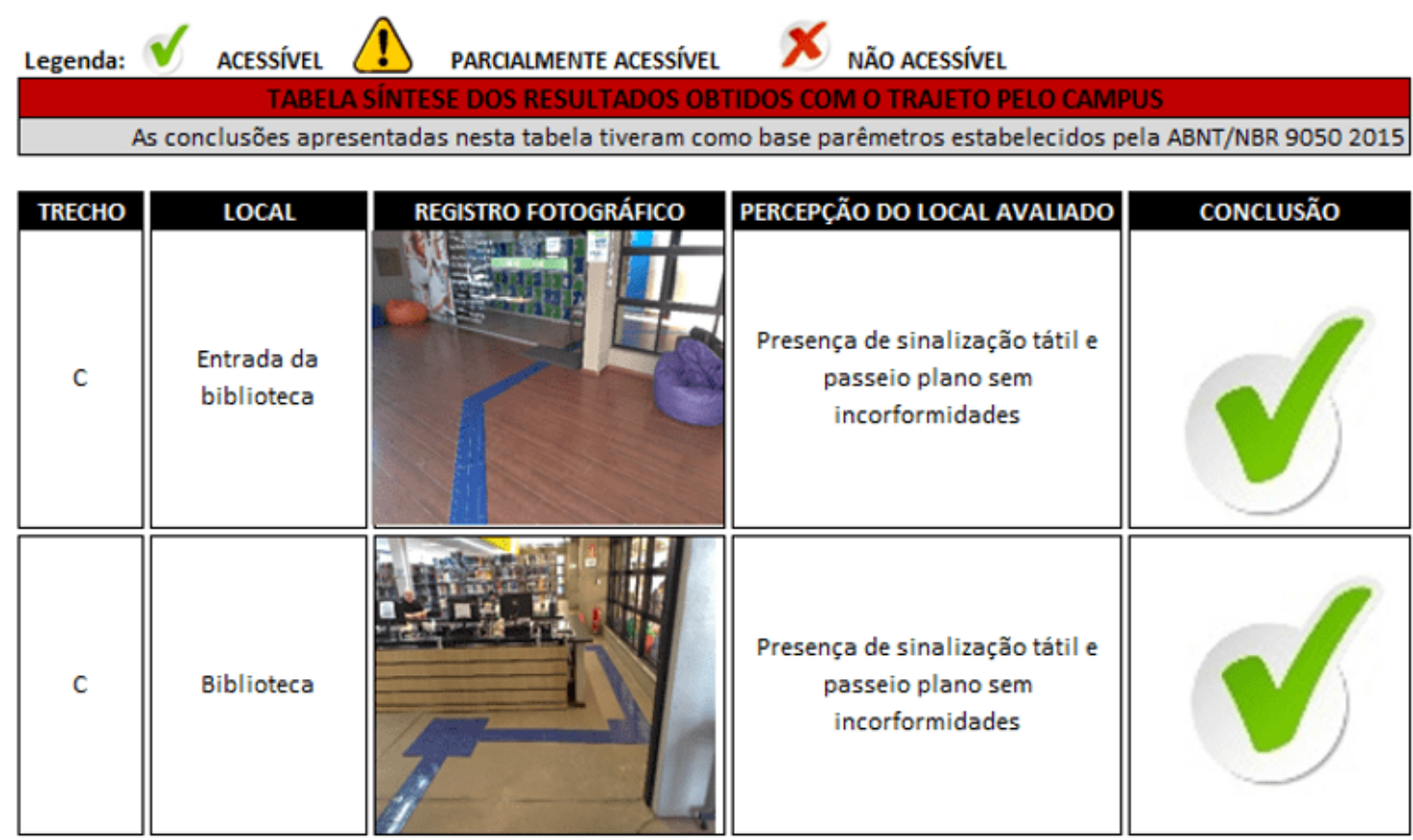

fonte: autor

O trecho $\mathrm{C}$ se caracteriza pela biblioteca, representada no mapa da figura 4 pelo ponto 4. Ela se encontra devidamente adaptada com sinalizações táteis, passeio nivelado, sinalizações visuais bem localizadas e também com terminais de computadores acessíveis a cadeirantes. 
Tabela 7 - Síntese dos resultados obtidos com o trecho D

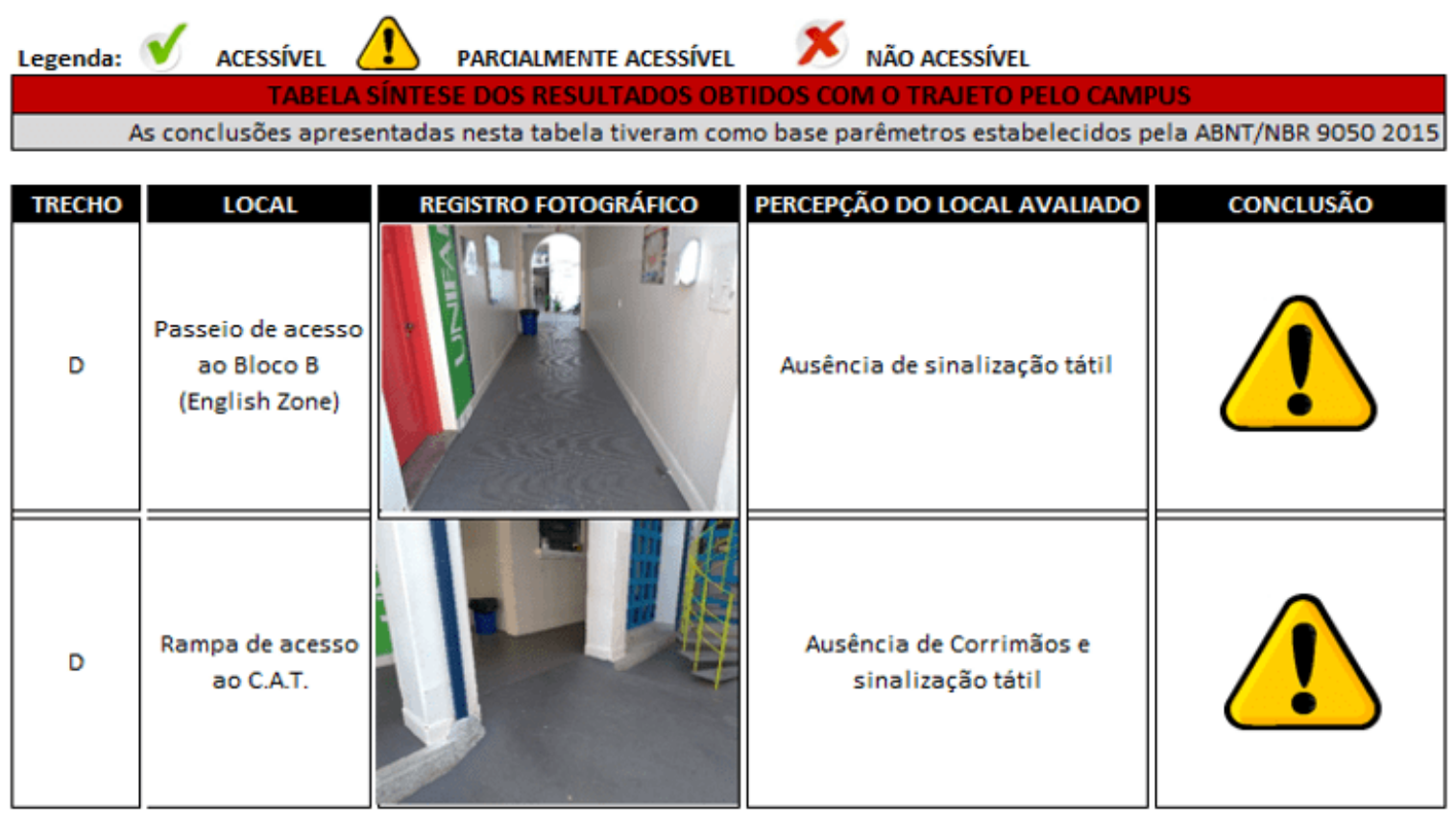

fonte: autor

O Trecho D é o ponto de acesso da área social ao Bloco B. Este se encontra também parcialmente adaptado, pois não conta com sinalizações táteis. $\mathrm{E}$ também a rampa de acesso ao C.A.T. (Centro de Atendimento Técnico) que apesar de sua inclinação se manter dentro dos parâmetros citados no referencial teórico, este local não possui corrimãos instalados.

A NBR 9050 deixa claro que: "Quando não houver paredes laterais, as rampas devem incorporar elementos de segurança, como guarda-corpo e corrimãos, guias de balizamento com altura mínima de $0,05 \mathrm{~m}$, instalados ou construídos nos limites da largura da rampa." ABNT NBR 9050 (2015, p. 60). 
Figura 5- Dimensões do guarda-corpo e corrimão para rampas

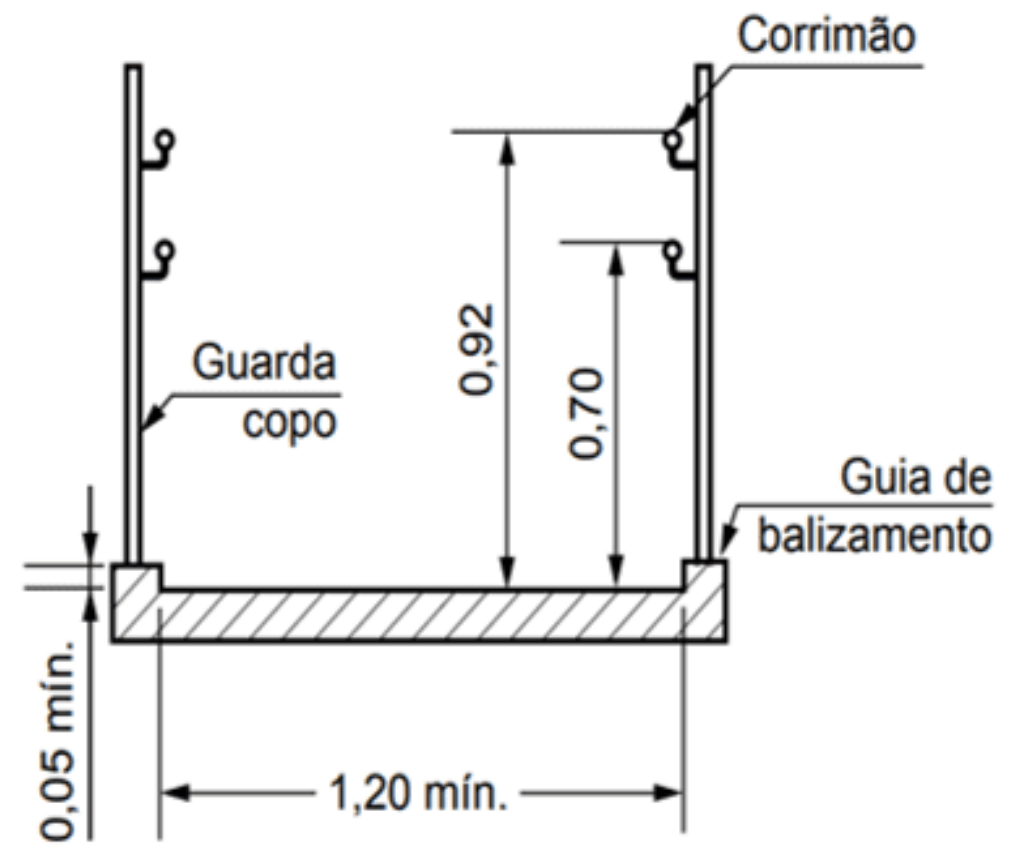

fonte: ABNT NBR 9050 (p. 60)

RC: 104683

Disponível em: https://www.nucleodoconhecimento.com.br/engenhariacivil/implantacao-de-acessibilidade 
Tabela 8 - Síntese dos resultados obtidos com o trecho E

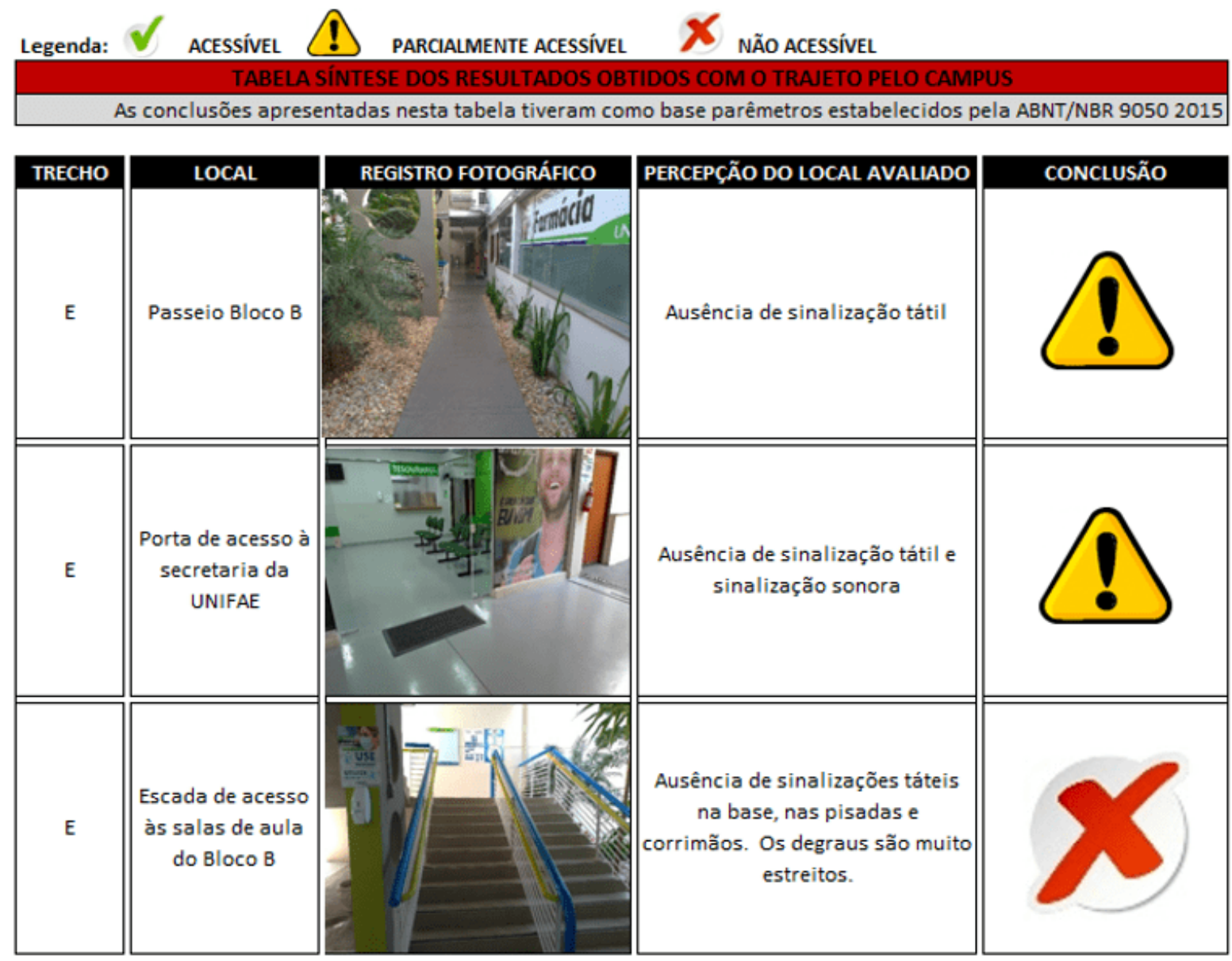

fonte: autor

O Bloco B é o local avaliado como o menos acessível da UNIFAE, no mapa da figura 4 é tido como o trecho $E$, o qual não conta com sinalização tátil em nenhuma parte de sua extensão, tanto sobre os passeio quanto na base/término das escadas de acesso aos pavimentos superiores do Bloco B. Conforme abordado acima na análise do Trecho A sobre as sinalizações táteis das escadas, o mesmo se aplica a estas escadas, somado ao problema desta possuir a pisada muito estreita, estreita demais até mesmo para pessoas sem deficiência alguma escorregarem ou se acidentarem.

Em relação à sanitários, apenas o sanitário presente no térreo se encontra devidamente adaptado, os superiores (feminino presente do 2 pavimento e masculino no 3 pavimento) possuem características em comum como: Falta de 
espaço de manobrabilidade (espaços com menos de $0,75 \mathrm{~m}$ de raio para manobra da cadeira de rodas) e barras de apoio próximas aos vasos sanitários e às pias.

O Bloco B não conta com elevador vertical, logo a Universidade conta com um projeto de instalação de um elevador nos fundos deste Bloco.

Tabela 9 - Síntese dos resultados obtidos com o trecho $\mathrm{F}$
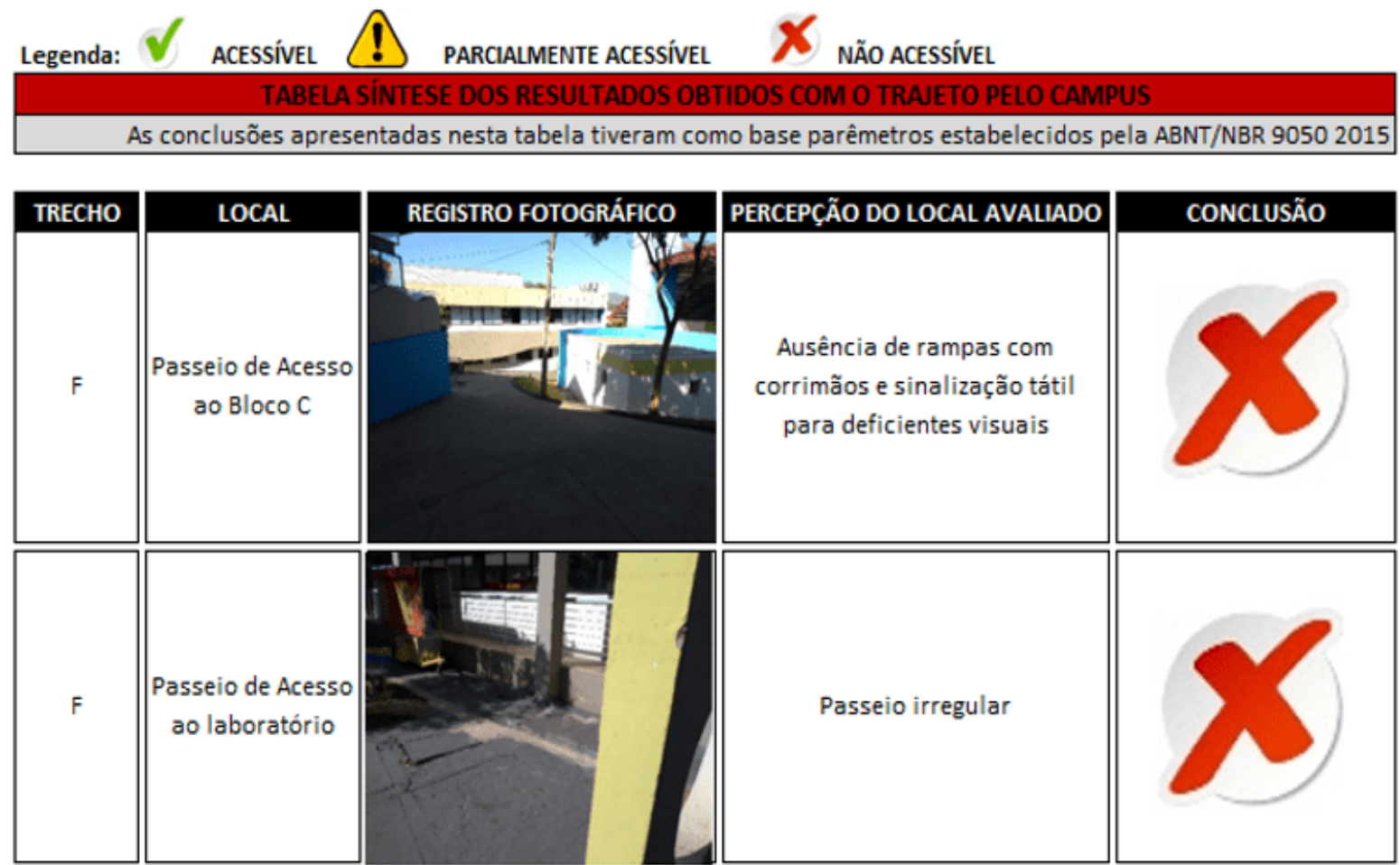

fonte: autor

O Trecho F é o caminho de acesso ao Bloco C e ao laboratório de Química da Universidade.

As inconformidades encontradas neste trecho são a ausência de rampas e corrimãos que suavizam e garantem a segurança para a descida e subida de indivíduos P.N.E. e P.M.R., conforme norma NBR 9050 (2015) referenciada na tabela 1, mencionada em tópico anterior. 
O passeio é completamente inacessível para portadores de necessidades especiais ou mobilidade reduzida, pois é acidentado contendo pequenas valetas e protuberâncias, estas que são mais do que o suficiente para derrubar facilmente uma pessoa desatenta.

Tabela 10 - Síntese dos resultados obtidos com o trecho G

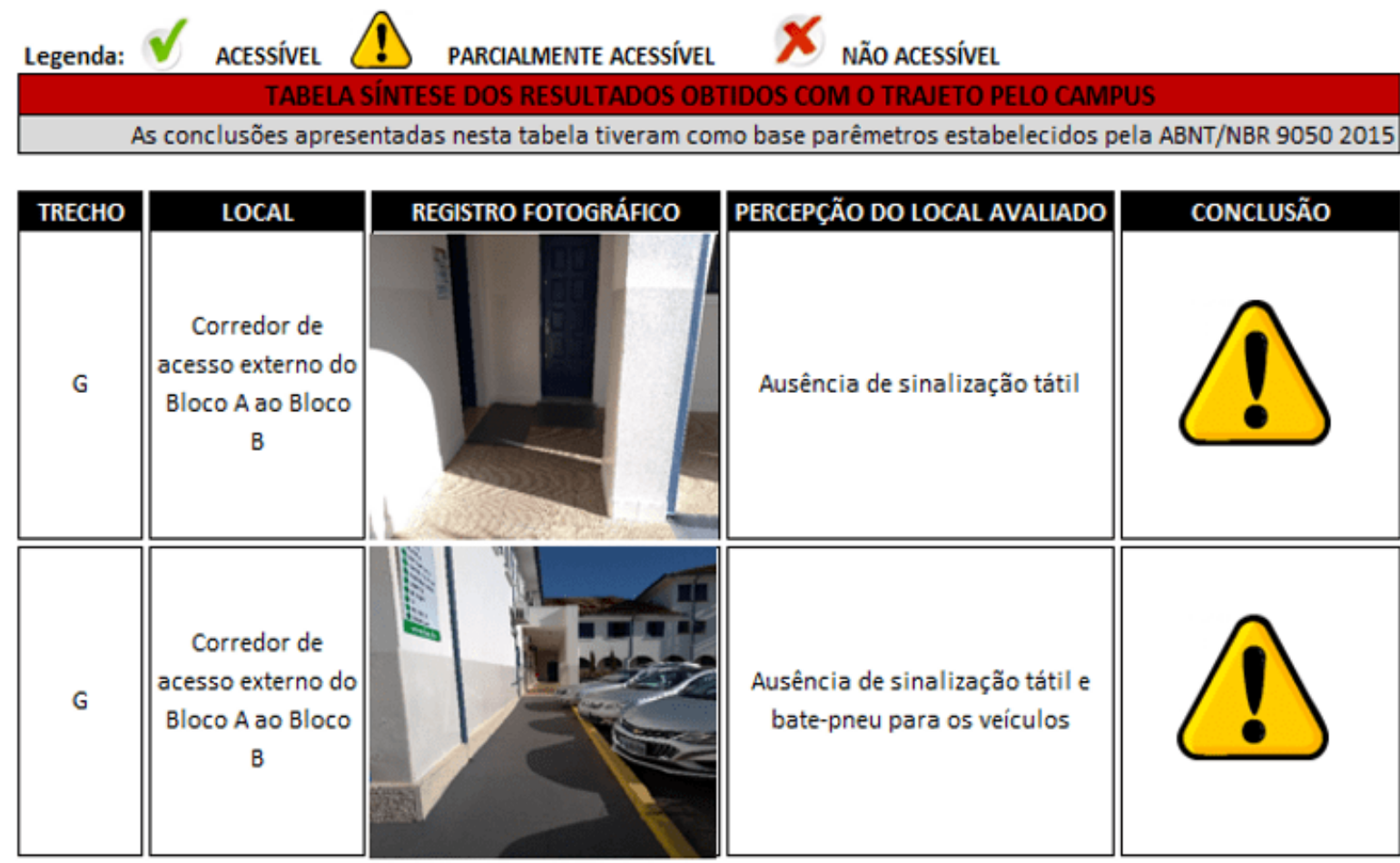

fonte: autor

O último trecho analisado é o Trecho $\mathrm{G}$. Este se caracteriza pelo corredor de acesso externo do Bloco A ao Bloco B. É muito utilizado por estudantes que procuram cortar caminho pela Universidade ou simplesmente acessar a secretaria de modo direto.

As inconformidades encontradas neste local foram a ausência de sinalização tátil no passeio somada à também ausência de guarda-corpo no canto esquerdo da rampa presente neste trecho.

É necessário a instalação de bate-pneus nas vagas de veículos paralelas ao trajeto, pois os carros estacionados nas vagas acabam ocupando parte do passeio.

RC: 104683

Disponível em: https://www.nucleodoconhecimento.com.br/engenhariacivil/implantacao-de-acessibilidade 
Para a facilitação em relação à localização, o grupo propõe a instalação de mapas táteis em todo o Campus. Eles permitem e facilitam a localização de indivíduos com deficiência visual e, conforme citado na norma, os "planos ou mapas acessíveis de orientação devem ser instalados, sempre que necessário, imediatamente após a entrada principal das edificações." ABNT NBR 9050 (2015, p.142).

Figura 6 - Mapa tátil

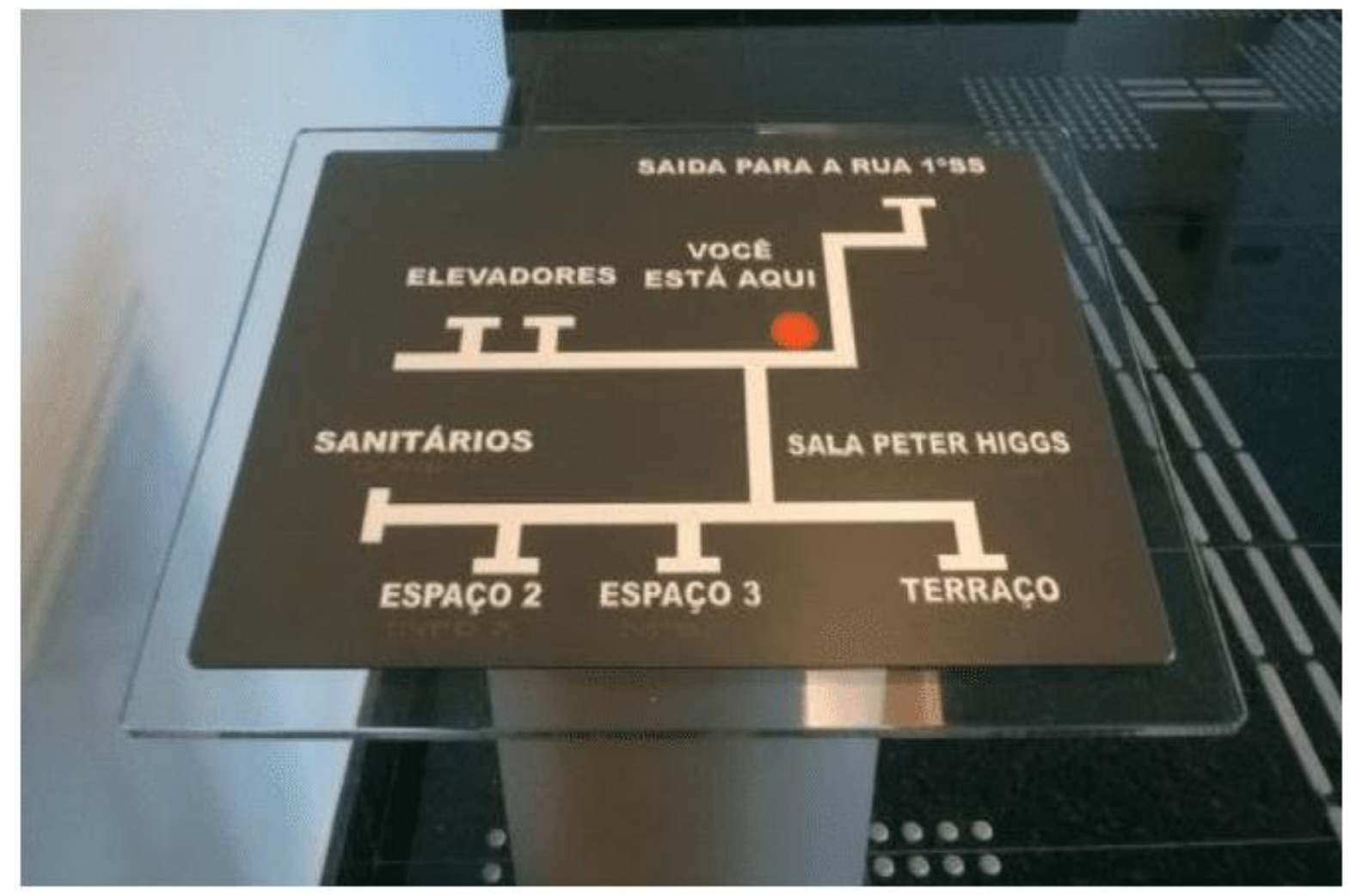

fonte: MS Acessibilidade

Ao serem atendidos os requisitos mais urgentes abordados anteriormente, a instituição (UNIFAE) irá se encontrar apta para receber a P.M.R e P.N.E com a maior segurança possível. 


\section{CONCLUSÃO}

O Campus da UNIFAE está em constante trânsito e aumento do número de alunos, com a abertura de novos cursos e em constante expansão com a adaptação dos vários Blocos, para atender essa demanda crescente.

Se a construção já for executada com um projeto já acessível, não há grandes acréscimos nos custos de construção a exemplo disto temos que para salas de aula acessíveis o acréscimo chega próximo de 0,13\%, porém se necessitar de uma reforma posterior para atender aos critérios de acessibilidade, o acréscimo pode vir a chegar a $25 \%$ do custo total da construção.(CONFEA, 2018)

Logo, se conclui que os pontos de estudo da universidade apresentaram diferentes níveis de acessibilidade, tendo o Bloco A com os melhores resultados, porém ainda parcialmente adaptado. Portanto, nenhum local atendeu por completo às condições estabelecidas pela ABNT NBR 9050:2015.

Sassaki (1997), inclusão não é um algo fácil, para alcançar este ideal é preciso que haja uma dedicação constante, as ações de cada pessoa, instituições e órgãos públicos, na difusão dos ideais necessários, a mudança não ocorre de forma rápida a inclusão é um trabalho desafiador e longo, que deve ser trabalhado pensando no ideal Não é um prédio adaptado, mas sim um prédio para todos, todavia não fugindo da realidade, a inclusão passa por ser o desejo de muitas pessoas para um futuro , o qual esperamos que seja logo.

Durante o trabalho, assim como constatado por Schmitz e Silveira (2019), a acessibilidade é um tema copioso o qual merece constante atenção, os ambientes requerem manutenção, visto que com o passar do tempo os elementos instalados para garantir a acessibilidade, vão se degradando, mas como consta na norma é obrigação a garantia de que ambiente continue acessível durante a vida útil da edificação. 
Em linhas gerais, torna-se imprescindível a execução das melhorias abordadas no presente trabalho, pois a acessibilidade é um requisito mínimo para a equidade de oportunidades entre as pessoas.

Logo, permitirá que a UNIFAE a atenda um novo público, não apenas em São João da Boa Vista, mas em toda a região, tornando-se um ícone em relação ao atendimento às pessoas com deficiência e mobilidade reduzida, por ser a instituição mais bem preparada e o único centro universitário com tal qualidade em estrutura na região.

\section{REFERÊNCIAS}

ANTUNES, E. M. e SIMÕES, F. A. (2013) Engenharia urbana aplicada: um estudo sobre a qualidade do transporte público em cidades médias. Revista Brasileira de Gestão Urbana, Curitiba, vol. 5, n. 2, p 51-62.

ASSOCIAÇÃO BRASILEIRA DE NORMAS TÉCNICAS. NBR 9050: Acessibilidade a edificações, mobiliário, espaços e equipamentos urbanos. Rio de Janeiro, 2015.

ASSOCIAÇÃO BRASILEIRA DE NORMAS TÉCNICAS. NBR 16537: Acessibilidade - Sinalização tátil no piso --Diretrizes para elaboração de projetos e instalações. Rio de Janeiro, 2016.

ASSOCIAÇÃO BRASILEIRA DE NORMAS TÉCNICAS. NBR NM 313: Elevadores de passageiros -- Requisitos de segurança para a construção e instalação -Requisitos particulares para a acessibilidade das pessoas, incluindo com deficiência. Rio de Janeiro, 2007.

BRASIL, 2015, Lei n. 13.146, de 6 de jul. de 2015. Lei Brasileira de Inclusão da Pessoa com Deficiência. Disponível em: <http://www.planalto.gov.br/ccivil_03/_Ato2015-2018/2015/Lei/L13146.htm>; acesso em: 22 abril 2020. 
BRASIL. Constituição (1988). Constituição da República Federativa do Brasil. Brasília, DF: Senado Federal, 1988. Disponível em : <http://www.planalto.gov.br/ccivil_03/constituicao/constituicao.htm>; acesso em 22 abril 2020.

BRASIL. Medida provisória oㅜ 917 de 31 de dezembro de 2019. Altera a Lei 13146, de 6 de julho de 2015, que institui a Lei Brasileira de Inclusão da Pessoa com Deficiência - Estatuto da Pessoa com Deficiência. Publicada em edição extra do Diário Oficial, Brasília, DF, 31 dez. 2019. Disponível em: <http://www.planalto.gov.br/ccivil_03/_Ato2019-2022/2019/Mpv/mpv917.htm>; acesso em 22 abril 2020.

CONFEA/Comissão Temática de Acessibilidade e Equipamentos - CTAE. Acessibilidade: Guia Prático para projetos de adaptações e novas normas. $2^{\underline{a}}$ ed. [s.l.]: [s.d.], 2018

IBGE - INSTITUTO BRASILEIRO DE GEOGRAFIA E ESTAtísticA. Censo demográfico: resultados - São Paulo. Rio de Janeiro, 2010.

INSTITUTO NACIONAL DE ESTUDOS E PESQUISAS EDUCACIONAIS ANÍSIO TEIXEIRA. Sinopse Estatística da Educação Superior 2018. Brasília: Inep, 2019. Disponível em <http://portal.inep.gov.br/web/guest/sinopses-estatisticas-daeducacao-superior>. Acesso em: 22 abr. 2020

MINISTÉRIO DA EDUCAÇÃO, Ano internacional das pessoas deficientes - 1981. Disponível em $<$ http://www.dominiopublico.gov.br/pesquisa/DetalheObraForm.do?select_action=\&c o_obra $=28678>$. Acesso em: 22 abr.

MOTTA, Lívia Maria Villela de Mello (2004). Tese (APRENDENDO A ENSINAR INGLÊS PARA ALUNOS CEGOS E COM BAIXA VISÃO UM ESTUDO NA PERSPECTIVA DA TEORIA DA ATIVIDADE) - Pontifícia Universidade Católica de São Paulo, p.63. 
SILVA, Otto Marques. "A Epopéia Ignorada: a pessoa deficiente na história do mundo de ontem e de hoje”. São Paulo: Cedas, 1987.

SASSAKI, Romeu Kazumi. Inclusão: construindo uma sociedade para todos. Vol. 174. WVA, 1997.

SCHIMTZ, A.; SILVEIRA, J. Condições de mobilidade e acessibilidade para cadeirantes: estudo de caso no campus da universidade de Santa Cruz do Sul UNISC. Braz. J. of Develop., Curitiba, v. 5, n. 4, p. 3690-3706, abril. 2019.

WORLD HEALTH ORGANIZATION \& WORLD BANK. (2011). World report on disability 2011. World Health Organization

Enviado: Janeiro, 2021.

Aprovado: Janeiro, 2022. 